\title{
Monsters in the capital: Helen Vaughan, Count Dracula and demographic fears in fin-de-siècle London
}

Article

Accepted Version

Renshaw, D. (2020) Monsters in the capital: Helen Vaughan, Count Dracula and demographic fears in fin-de-siècle London. Gothic Studies, 22 (2). pp. 148-164. ISSN 2050-456X doi: https://doi.org/10.3366/gothic.2020.0046 Available at https://centaur.reading.ac.uk/84075/

It is advisable to refer to the publisher's version if you intend to cite from the work. See Guidance on citing.

To link to this article DOI: http://dx.doi.org/10.3366/gothic.2020.0046

Publisher: Edinburgh University Press

All outputs in CentAUR are protected by Intellectual Property Rights law, including copyright law. Copyright and IPR is retained by the creators or other copyright holders. Terms and conditions for use of this material are defined in the End User Agreement.

www.reading.ac.uk/centaur

\section{CentAUR}


Central Archive at the University of Reading

Reading's research outputs online 


\title{
Monsters in the Capital: Mrs Beaumont, Count Dracula and Demographic Fears in fin- de-siècle London
}

\begin{abstract}
This article examines the confluence of fears of demographic change occasioned by Jewish migration to Britain between 1881 and 1905 with two key gothic texts of the period - Arthur Machen's Great God Pan and Bram Stoker's Dracula. The descriptions of the activities of the demonic protagonists Mrs Beaumont and Count Dracula in London will be compared with contemporary depictions of Jewish settlement by leading anti-migrant polemicists. Firstly, it will consider the trope of settlement as a preconceived plan being put into effect directed against 'Anglo-Saxon' English society. Secondly it will look at ideas of the contested racial inferiority or superiority of the 'other'. Thirdly the article will examine the imputed chameleonic natures of both gothic monsters and Jews rising up the metropolitan social scale. The article will conclude by comparing the way Machen and Stoker's 'heroes' deal with their opponents with posited 'solutions' for the Eastern European immigration 'problem'.
\end{abstract}

\section{Key Words}

\section{Bram Stoker, Arthur Machen, Anti-Semitism, Migration, London}

The imagery of invasion that was such a feature of British cultural discourse at the end of the nineteenth and beginnings of the twentieth centuries oscillated between two conceptions of enforced foreign control. On the one hand take over was conceived as something obvious, sudden, overwhelming and external in nature. This school of invasion scenario imagined triumphant cavalry divisions trooped in strange colours making their way through defeated British city streets and country lanes. At other times the threat was insidious, the enemy 
already located within the British body politic - be it German waiters, Russian spies or Chinese diplomats facilitating the subjugation of Britain from within by foreigners. ${ }^{1}$

Emerging concurrently with the proliferation of sensationalist literature predicting foreign aggression and Britain lying prone before an external threat in the 1880s and 1890s was a discourse that focused on a posited invasion of another kind. This centred on the consequences of migration to the United Kingdom, and in particular the radical demographic changes associated with it. By 1890 the discourse on the threats posed by immigration were overwhelmingly focused on one group - Jewish refugees fleeing the pogroms in Russia, Poland and Romania. In this period 'migrant', 'alien' and 'Jew' became almost synonymous as terms. ${ }^{2}$

This article will examine how the language of demographic displacement directed against Jewish arrivals by anti-migrant groups was reflected in another source of violent, over-heated and heavily sexualised fin-de-siècle discourse, the gothic narrative. Some late-Victorian authors who worked in the gothic mode, such as Arthur Conan Doyle, H. Rider Haggard, Richard Marsh and Rudyard Kipling, positioned the 'other' in the colonial or transatlantic territory, ready to return to and seek revenge on the imperial capital. For Robert Louis Stevenson and Oscar Wilde, the gothic 'other' was present in the capital from the start, waiting to be unleashed from within bourgeois society. This article will focus on the confluence of the language and imagery of anti-migrant literature, and in particular fears of demographic usurpation, with that of the depiction of two late-gothic 'monsters' present in the imperial hub; Bram Stoker's vampire aristocrat Count Dracula and Arthur Machen's occult sexual transgressor, the protagonist of The Great God Pan (1890), who begins her life as Helen Vaughan, soon to become Mrs Herbert and finally Mrs Beaumont. 
Bram Stoker's Dracula is now one of the most closely scrutinised of all modern novels. ${ }^{3}$ There can be few other texts upon which so many inferences and interpretations have been drawn. Dracula even has its own occasional journal devoted to dissecting its themes. ${ }^{4}$ The book has been held up as a key example of gothic 'reverse-colonisation' - with Stephen D. Arata's 'The Occidental Tourist' being the pioneering work in this respect. ${ }^{5}$ There has been a substantial amount of discussion on the racialisation of vampires in general and Dracula in particular, and the overlap of anti-Semitic imagery and conceptions of the undead in pre-First World War Europe. This has focused on Dracula's physiognomy as described by Stoker, Dracula's relationship with money, and, most potently, the confluence between the antiSemitic blood libel and the murder or victimisation of children in the novel. ${ }^{6}$ For Judith Halberstam '.. the vampire embodies and exhibits all the stereotyping of nineteenth century anti-Semitism... The vampire merges Jewishness and monstrosity. ${ }^{77}$ Jules Zanger in a 1991 article on Dracula and Jewish stereotypes linked the villainous Count with two classic Victorian anti-Semitic literary figures - Charles Dickens's Fagin and George du Maurier's Svengali. $^{8}$ As to the confluence of blood, sex and foreignness in the novel, religious transgression and the rejection of Christianity, physical appearance and the gothic appropriation of Lombrosian theories of criminality, these themes have now been extensively mined, and this article will not substantially repeat these arguments. ${ }^{9}$

Compared to Dracula, Mrs Beaumont is rather less prominent in contemporary discussions of the relationship between the gothic and the 'other', although Machen's novella has been rightly celebrated by critics as a classic of its kind ${ }^{10}$ Perhaps the key factor in the disparity in popular awareness of the two works is the neglect of Machen's canon by the cinema in the twentieth century. Although various cinematic interpretations have taken great liberties with Bram Stoker's plot, the basic outline of Dracula is well-known, through Hollywood and Hammer, and has become one of the key cultural signifiers of the modern era. ${ }^{11}$ Machen's 
short stories and novellas, and Pan in particular, were much lauded by later writers including Algernon Blackwood and H.P Lovecraft, with the latter's thematic debt to Machen being profound. ${ }^{12}$ But Machen's fictional work on the occult did not achieve long-term popular cultural awareness as Dracula so strikingly has done. ${ }^{13}$

Arthur Machen's novella, therefore, merits some elucidation. The Great God Pan begins with a scientist about to practice cranial surgery on a young woman that will allow her contact with the supernatural. Nine months later the woman, driven insane by her experiences, gives birth to a daughter, whose father may be the Greek (or Celtic pagan) semi-deity Pan. The novella documents Helen Vaughan's childhood in the Welsh countryside, and the uncanny and sometimes terrifying influence she has on her young playmates. The narrative then breaks off and resumes in London, employing the device of multiple perspectives similar to both Dracula and Willkie Collins's work. The tale takes on the form of a horrific detective story as the details of the demonic female's sexual and moral corruption of various men are pieced together by the protagonists. Vaughan/Beaumont repeatedly appears and reappears in different guises under different names. The novella ends with the brutally-described enforced suicide of Mrs Beaumont. Helen Vaughan, who becomes Mrs Beaumont, is not a vampire, but the story creates a tension and at times inspires a visceral fear that matches the most terrifying parts of Dracula.

In common with the approach to many late-Victorian gothic texts containing female monsters, initial analysis of The Great God Pan focused on the gender and sexual, rather than ethnic, transgressions committed by its protagonist, although this discussion has been expanded to encompass a wider range of explicit or implicit underlying themes. ${ }^{14}$ Most recently, James Machin has challenged S.T Joshi's sexualised interpretation of The Great God Pan, and instead located it as variously a commentary on the limitations and dangers of science, a critique of Christianity, or a discussion of the plasticity of the human form. ${ }^{15}$ Pan 
was seen by contemporary observers as symptomatic of a decadent decade, of yellowcovered books and The King in Yellow, supine men and aggressive predatory women, the belle dame sans merci, the era of Oscar Wilde and Philip Burne-Jones, and was initially (and often subsequently) viewed in the context of moral decadence and sexual violence by critics. $^{16}$

This article will examine how fears of demographic change brought on by large-scale Jewish migration to the East End of London shared confluences of discourse with those of the two 'monsters'. Four points will be addressed. Firstly, the concerted nature of settlement will be discussed - the belief that for both 'monsters' and migrants settlement in London was not accidental, but that a deliberate plan was being worked out in the capital. Secondly, the article will address ideas of racial superiority and vigour, and the fear that both gothic villains and migrant Jews might in fact be racially more dynamic than the society that they were settling in. Thirdly, the mutability of migrant transnational identity will be discussed, the ability of monsters and migrants to 'pass' in the wider society, and fears surrounding the adoption of monstrous 'others'. Finally, posited solutions, both to the intrusions of Dracula and Mrs Beaumont and to mass Jewish migration, will be analysed. As well as Bram Stoker and Arthur Machen, the article will draw primarily upon the writing of three key fin-de-siècle anti-migrant campaigners - the journalist Arnold White, the leading light of the British Brothers' League W.H Wilkins, and, at the peripheries of extreme anti-Semitism, the polemicist Joseph Banister - each representative of a different strand of anti-migrant discourse. The article will posit that neither Machen nor Stoker were explicitly anti-Semitic writers, but rather that their work drew from a prevalent and underlying angst that manifested itself, to a degree on an unconscious level, in their most famous creations. In this analysis the gothic text inevitably reflects the prejudices of its period, even if that reflection is not a preconceived component of the work, or of its 'monsters'. In other words, migration and 
responses to migration in the 1890 s formed such an important part of the collective consciousness that they intruded significantly into arenas which on the surface they had no obvious connection with.

\section{Migration as Conspiracy}

At the heart of both the anti-migrant discourse on Jewish refugees and The Great God Pan and Dracula was the belief that the arrival and settlement of the 'other' in the capital was no mere accident, but part of a concerted and pre-conceived plan being put into action. For the anti-Semite, Jewish settlement in London was not the product of a haphazard process of chaotic migration westwards, but part of a wider scheme to assert Jewish control over the host society. The rapid demographic transformation of the East End and other areas was stressed by W.H Wilkins: '... and where there were then two Jews, there are forty now, or even more -say sixty. I know a street which when I was a boy there was not a single Jew in, and now it is completely full of them. ${ }^{17}$ He continued: 'Thus whole districts in the East of London are as foreign as Warsaw, or the Ghetto - when there was a Ghetto - in Rome. ${ }^{18}$ This was a narrative of deliberate (and rapid) supplanting of the 'native' inhabitants of the East End.

For Joseph Banister, Jewish migration was orchestrated as a means to corrupt and orientalise the host society. Not only that, but having gained entry to Britain, Jews in general (Banister refused to distinguish between English-born and migrant Jewry) were now plotting to undermine Anglo-Saxon racial stock by facilitating the immigration of other groups including Italian and Chinese migrants:

The Jews not only compose the most numerous and undesirable element among our foreign invaders, but are at the head of the various movements for bringing other obnoxious aliens to this country. The vile looking Italians one sees laying 
the asphalt in our streets are imported by a company composed of Jews. The introduction of foreign women for immoral purposes is carried on, as is the white slave trade everywhere, chiefly, if not entirely, by Jews... the attempt to introduce swarms of Chinese laundrymen into England was made by Jews, and received its support chiefly from Jews, and Jew controlled newspapers. ${ }^{19}$

The idea that Jewish migration constituted a considered and thought-out campaign, a planned invasion or even a form of coup d'état, was also advanced by Arnold White in The Modern Jew (1899): '[The English] will wake up one morning only to discover that they have parted with the realities of national life, and are dominated by cosmopolitan and materialist influences fatal to the existence of the English nation.' ${ }^{20}$ For all three anti-migrant campaigners, settlement in London was not a matter of chaotic individual agency on the part of refugees escaping an intolerable situation, but an organised attack by a diasporic 'nation'

Both Mrs Beaumont and Count Dracula approach their assaults on London in a carefully considered and planned manner. Dracula plots his first moves to take over the capital whilst still in Transylvania. At the beginning of the novel Jonathan Harker notices in Dracula's rooms books on 'history, geography, politics, political economy, botany, geology, law - all relating to England and English life and customs and manners. ${ }^{21}$ Once in London, Dracula carefully distributes his coffins/base of operations in both rich and poor areas of the city. Dracula does not merely want blood for sustenance - he wants control, the creation of a vampire empire. ${ }^{22}$ At one point Dracula is described as 'instinctive' in his actions, but there is much evidence that his deeds are part of a carefully considered long-term strategy. Cornered by his enemies, Dracula sneers that 'My revenge is just begun. I spread it over centuries, and time is on my side' (365). Similarly, Mrs Beaumont carefully choses her male victims from the upper echelons of the British aristocracy and the cultural and political elite, using her (literally) unspeakable practices not merely for pleasure, but to advance her own socio- 
economic position. Her first partner/victim - Charles Herbert, comes of noble family, destined to 'succeed to an excellent place in Devonshire' upon his father's death. ${ }^{23} \mathrm{~A}$ subsequent victim is described as '[A] gentlemen, a man of very good position', while another is a peer of the realm (214). The gothic monsters, like 'the Jew' in anti-Semitic discourse, are comfortable both in high society and the poorest slums. They are to an extent chameleonic and classless in a society stratified by social positon. Mrs Beaumont, like Stevenson's Mr Hyde, has a base in Soho. Stoker writes that control of the East End is part of Dracula's plan. ${ }^{24}$

Superiority, 'Vigour', and Inferiority

A factor in the potency of the monstrosity of both Dracula and Mrs Beaumont was their perceived challenge to an Anglo-Saxon superiority at the heart of the wider British imperial project. Arata in his work on Dracula and reverse colonisation argues that the paramount threat that Dracula poses, more so even than the sexual corruption of the female characters by the vampire, is the possibility that he may in fact be of superior racial stock to his AngloSaxon opponents. ${ }^{25}$ Dracula, in the one part of the novel in which he speaks at length of his own experiences and sentiments, proudly informs Jonathan Harker of a lineage dating back to Attila. 'Is it a wonder that we were a conquering race, that we were proud?' (41). Helen Vaughan, who becomes Mrs Herbert and finally Mrs Beaumont, not only has classical Greek heritage, the well-spring of western civilisation that the British Empire at least partly viewed itself as continuing, she literally, through her god/devil father, has immortal lineage. Vaughan has occult powers far greater than her merely human opponents. The threat posed by the two monsters is not just degeneracy - it is possible superiority to their opponents. Both Dracula and Mrs Beaumont are the products of societies perceived as racially elevated that have since declined. For Banister Greece itself served as a warning of the future that a Britain weakened by large-scale Jewish migration faced: '[if immigration] continues it is only a matter of time 
when the majority of the inhabitants of London, and other large English towns, will have as much right to be described as Anglo-Saxons, as have the present mongrel inhabitants of the Hellenic Kingdom to be called Greeks. ${ }^{26}$ But Mrs Beaumont is from that original Hellenic culture, from which she takes her first name. This analysis is complicated in that Machen also suggests a pagan Celtic origin for Beaumont, a heritage associated with victimhood and centuries-old subjugation by a more 'vigorous' Anglo-Saxon entity, an oppression that formed the cornerstone for the wider British imperial project of the eighteenth and nineteenth centuries. ${ }^{27}$

Similarly, although the Jewish migrant 'other' was portrayed as both physically and morally inferior to the 'native' English worker, anti-Semitic polemic also stressed that Jews, with their Israelite legacy, were part of a conquering race. This discourse was not limited to the anti-migrant right. In Life and Labour of the People in London the Fabian socialist Beatrice Potter wrote that 'The Polish and Russian Jews have centred their thoughts and feelings in the literature of their race - in the Old Testament, with its magnificent promises of universal domination; in the Talmud, with its minute instructions as to the means of gaining it. ${ }^{28}$ Both William Evans Gordon, founder of the British Brothers' League, and Cosmo Lang, Bishop of Stepney, referred to the non-Jewish East Ender as a modern Canaanite, soon to be displaced by the Israelite, whilst also making use of the imagery of the plagues of Egypt. ${ }^{29}$ Arnold White also positioned Jewish migrants as modern-day Israelites, writing that '...they preserve their tribal customs; they are too proud of their origin and their destiny not to feel contemptuously towards the people by whom they are sheltered and on whom they exist.' 30 Antiquity and a two thousand year diasporic identity in this discourse becomes an explicit challenge to a 'young' nation like Britain, just as Beaumont and Dracula are 'old' beyond human reckoning. 
In other words, although presently disenfranchised and powerless, in anti-Semitic polemic the Jewish migrant, like Dracula and Helen Vaughan, had once been part of a dominant race, and had the potential to become so again. ${ }^{31}$ This is a thematic thread running throughout the work of Arnold White. 'The mild spirit of Christian forbearance has promoted the undue economic predominance of a more powerful and intolerant race.' ${ }^{32}$ White in The Modern Jew also discussed a revival of the Israelite spirit, particularly in regard to Jewish agricultural colonies in Russia, an early precursor to the kibbutz: '... the difference is amazing. I found the latter an active, well set-up, sunburnt, muscular agricultural population, marked by all the characteristics of a peasantry of high character... enough to show what stuff is in Israel. ${ }^{33}$ This potential was both positive and negative in its implications.

For White, who combined in his work familiar anti-Semitic tropes of Jewish control with guarded admiration for certain characteristics he defined as 'Jewish' and issued condemnations of the violent anti-Jewish sentiment of the 'mob' in Eastern Europe, Jews possessed the pre-requisites necessary for a quality much esteemed in the late-Victorian imperial world-view; 'vigour'. However, this needed to be set free by a wholesale removal from the stultifying restrictions of the Pale of Settlement. White himself suggested Argentina as an appropriate setting for the renaissance of Jewish virility. In his polemic White stressed that the Jewish reconnection with a dynamic Israelite past must take place on the geographical margins, not in London (or even by preference, Europe). Banister in his antiSemitic diatribes also made reference to a potential Jewish homeland or return to Palestine, albeit in the sneering and near-hysterical tone that marked all of his prose:

[If] he ever returns to his Asiatic home, he will probably evince about the same capacity for self-government, and the same love of progress, tolerance, and personal freedom which other Asiatic breeds display. It is only when the Jew insists upon posing as a European that one realises what an obnoxious creature he 
is, and how utterly out of place he is in a European country and in European society. $^{34}$

These tropes of power and weakness discussed above also connect anti-Semitism with sinophobia - both the Jewish and Chinese 'others' were viewed as powerless, but with the potential for achieving future domination over 'Anglo-Saxon' Britain, drawing on an imperial legacy. ${ }^{35}$ Anti-migrant polemic in the 1890 s and 1900s intertwined the two sources of racial paranoia - one article on the East End in Blackwood's Magazine from 1901 imagined a racialised future for the eastern parts of the capital emerging from miscegenation between Chinese immigrants and Polish Jews, with the extinction of the 'native' population as a result. ${ }^{36}$

'Passing' and Assimilation

The potency of the threat of the vampire count and the demonic femme fatale was accentuated by the elasticity of their identities, their ability to change how they were perceived by the society they were threatening, both figuratively and literally shapeshifting. ${ }^{37}$ Dracula and Mrs Beaumont change their names on arrival in London. Stoker has Dracula adopt the identity of Count De Ville once he settles in the capital. Clive Leatherdale amongst others has identified this as evidence of Dracula as Christian parable, but it also is indicative of the anglicisation of Dracula once he arrives in London. ${ }^{38}$ Dracula indicates his determination to 'pass' (even at the expense of his own aristocratic identity) in the capital to Jonathan Harker whilst still in Transylvania: 'I am content if I am like the rest, so that no man stops if he sees me, or pause in his speaking if he hear my words, to say, "Ha ha! A stranger!" (31). Dracula also explicitly frames this desire to 'pass' in the language of control, his aim to be 'master', in London as in his Eastern European home. ${ }^{39}$ 
Machen's monster changes name repeatedly as she rises through fashionable society. Beginning as plain Helen Vaughan, she then becomes 'Miss Raymond', 'Mrs Herbert' and finally 'Mrs Beaumont'. To quote Charles Herbert, one of her first victims 'what her real name was I can't say. I don't think she had a name. No, not in that sense. Only human beings have names...' (199). Both Dracula and Mrs Beaumont 're-invent' themselves on arrival in London. Both are wealthy, but have made their money abroad, under uncertain circumstances - Dracula in Eastern Europe, Mrs Beaumont in South America. Mrs Beaumont's mysteriously-gained wealth allows her partial access to elite metropolitan circles: 'I heard she comes from South America, but after all, who she is is of little consequence. She is a very wealthy woman, there's no doubt about that, and some of the best people have taken her up' (210-211). In other words, currency has given the demonic female access to avenues of power and influence she would otherwise not enjoy.

This uncertainty and malleability of identity also played a key role in anti-migrant discourse. Jews rising up the economic and social scale in metropolitan London adopted anglicised names. West End Jewish rabbis adopted the apparel of the Protestant pastor or vicar. For the anti-Semite, this willingness to integrate and anglicise was not a positive phenomenon - as with gothic monsters advancing their plans under respectable anglicised aliases, the threat was only increased by this willingness to merge. Arnold White wrote that Jews '...reflect, like the chameleon, the texture and the tint of the rock on which they rest. ${ }^{, 40}$ Assimilation was demanded, yet became a threat when it was achieved. There is a contradiction apparent here. Jews were condemned and compared unfavourably to past Protestant refugee groups for remaining separate and apart from the wider society, yet the supposed challenge presented only had its potency increased by successful assimilation. Similarly, Dracula and Helen Vaughan remain 'monstrous', 'bestial' and recognisable in London (by those who know what to look for), yet also attempt to hide their identities and to reinvent themselves. 
Like Mrs Beaumont returning from South America, Jews returning from the Transvaal, having made money in mineral mining, were viewed as on a fundamental level disreputable, their fortunes made in questionable and mysterious circumstances. ${ }^{41}$ Wealth bought partial entry into society, but the suspicions remained. With the exception of the Rothschilds, who achieved the status of something approaching a Jewish royal family, a patrician prejudice continued to surround even the wealthiest Jewish families, Anglo-Jewish or migrant. ${ }^{42}$

The Jewish arriviste became a familiar figure both in late-Victorian reportage and in the fiction of the period. An example in gothic literature is the character Baron Steen in the B. Fletcher Robinson short story 'The Terror in the Snow' (1904). Steen, who is eventually revealed to have been indulging in fraudulent practices on the stock market (and is murdered in a brutal and apparently supernatural manner), rents the country pile in which the story is set from an impoverished aristocrat described as 'a broken-down old drunkard [but whose] family had been a great and glorious one, finding mention on many a page in English history. ${ }^{43}$ For the anti-Semite, West End Jewish wealth, like East End Jewish poverty, was a threat to 'Anglo-Saxon' hegemony. As the Jewish migrant in Spitalfields converted Huguenot chapel into synagogue, so the Jewish interloper into high society took control of country estates which shabby-genteel 'English' aristocrats could no longer afford to own and maintain. 'As a rule these foreign Jews are well-to-do. They deny themselves nothing. They spend freely the gains which they have acquired by superior sharpness over the native born. ${ }^{44}$ This supposed prosperity, and the material influence that was posited to come with it, was couched in semi-positive terms ('they spend freely'), but was still symptomatic of an anti-Semitic framework of discourse.

Like the migrant arriving in the East India docklands on the Thames, Mrs Beaumont and Dracula 'begin again' in the metropolis. One of the characters in The Great God Pan describes London as 'the city of Resurrections.' (197). Both are simultaneously young and 
ancient - Dracula has lived for four hundred years, and yet, as Van Helsing makes clear in his summary of Dracula's powers and weaknesses, 'In some faculties of mind he has been, and is, only a child; but he is growing, and some things that were childish at first are now of man's stature' (360). Helen Vaughan is not quite twenty-three when she is murdered (or rather forced to commit suicide), and at the same time a conduit to a pagan past of millennia ago; Celtic, Roman and Greek (231). Both Mrs Beaumont and Dracula are at the same time cosmopolitan; Beaumont has variously been a resident of Argentina, New York, Mexico and California, as well as all over London and other locations (218). In anti-migrant discourse the Jewish refugee was both a blank slate, a stateless unknown without allegiance upon which any political, social or economic fantasy could be projected, and simultaneously, as discussed above, the living representative of a well-documented Israelite past as described in the Old Testament.

The circumstances in which Helen Vaughan begins her career highlights another area of concern for anti-migrant writers in the 1890s - the Jewish migrant as 'cuckoo' or concealed in an Anglo-Saxon/Celtic nest. Helen Vaughan is fostered by an impeccably respectable 'British' family in the Welsh countryside. Her foster-parentage helps to camouflage her malevolent schemes. The early parts of The Great God Pan, in which her childhood in a quintessentially Welsh pastoral setting is described, are some of the most effective and uncanny sections of the novella. They form a supernatural precursor to the sexual and societal transgressions to follow when Vaughan becomes an adult. Before her corruption of the metropolitan elite, Helen Vaughan practices on childhood peers. Even as a child, Vaughan represents an unsettling 'other' in rural Wales, described as '...of a very different type from the inhabitants of the village... Her skin was a pale, clear olive, and her features were strongly marked, and of a somewhat foreign character' (192). This description is strongly reminiscent of contemporary descriptions of migrant Jews. Yet Vaughan is also 
'camouflaged' and hidden to a degree, before her behaviour forces her to move on and change location.

In 1892 a certain Count Mazeppa, in a tract on the dangers of (Jewish) immigration to Britain, had warned about 'large numbers of fully-qualified, nominally British, though organically FOREIGN-citizens [sic]' resident in London. ${ }^{45}$ Joseph Banister in particular obsessed about the possibility of 'Jewish blood' running in the veins of apparent 'non-Jews', i.e. a 'secret' Jewish identity. ${ }^{46}$ One result of this demographic paranoia was the belief that the Jewish population of the United Kingdom was in fact far higher than censuses would suggest. To quote Banister in England Under the Jews: 'It is safe to estimate the present Jewish population of the United Kingdom at not less than 400,000. It is probably much larger... ${ }^{47}$ Jews could also potentially 'pass' in English society through conversion to Christianity during childhood. In Banister's biological racist worldview however, conversion was irrelevant. 'It is the Jew's nature and race which render him objectionable, not his religion. ${ }^{48}$ For Banister, whatever faith was followed, the only answer was enforced expulsion.

Jewish influence over non-Jewish children in the board schools located in areas of high Jewish settlement such as the East End was also a common trope in the language of migrant invasion. In the build-up to the passing of legislation restricting entry into the United Kingdom, the demographic changes taking place in East London schools was stressed. Conservative politicians also emphasised the dangers of Christian children being taught by Jewish schoolteachers. ${ }^{49}$ This paranoia over the instruction of children is apparent in the chapters of Dracula dealing with the 'bloofer lady'. Lucy Westenra, herself a young woman corrupted, could be viewed as compulsorily 'adopting' 'English' children into Dracula's vampire family. This is part of Dracula's scheme for metropolitan conquest - his aim to 'create a new and ever-widening circle of semi-demons' (67). 


\section{Difficulties}

There are challenges presented by the analogies this article has posited between the gothic monster as represented by Mrs Beaumont and Count Dracula and the language used to express fears of demographic change occasioned by Jewish migration. Neither The Great God Pan nor Dracula can wholly be described as an overtly anti-Semitic text, although in the latter case this has been argued by some critics. ${ }^{50}$ It is true that the one obviously Jewish (very minor) character in Dracula is a stock caricature, and plays a negative role, facilitating the escape of the Count from England. Yet, compared with much contemporary sensational literature, and indeed the popular fiction of the Edwardian and inter-war periods that followed, Dracula is light on explicit, up-front racism. The same cannot be said of Stoker's last piece of gothic fiction, The Lair of the White Worm (1911), which contains a jarring and abrupt racialised rant about an African protagonist, or in earlier stories such as The Man (1905). ${ }^{51}$ There is some evidence that in his original conception of the novel Stoker intended that Jewish characters would be more prominent. Harker's employer (Peter Hawkins in the final draft) was initially to be called 'Abraham Aaronson'. ${ }^{2}$ The conflation of the person of Dracula and the Jewish migrant 'other' is also problematic; in particular because of Dracula's class status. As William Hughes has discussed, in his Eastern European home Dracula is boyar. ${ }^{53}$ In other words, in Romania (which along with Poland and the Ukraine was one of the main sites of anti-Semitic persecution in the late nineteenth century) Dracula as an aristocrat would be directing the pogroms, not a victim of them. In The Great God Pan there are no explicitly Jewish characters at all.

Yet both texts are saturated in a fear about demographic change taking place in London, as well as the obvious fear of changes in gender roles signified by the sexual transgressions of the monsters. This demographic threat need not be explicitly Jewish; it could be sinophobic or anti-Catholic in character. But at the time when both gothic texts were written in the 
1890s, it was Jewish migration into Britain that was so exercising those writers concerned with the protection and furtherance of 'Anglo-Saxon' racial stock. Anti-Semitism also had an added potency that distinguished itself from sinophobia or colonial forms of racism, the ability of the Jewish 'other' to pass as a non-Jew in metropolitan society. In both The Great God Pan and Dracula the horror is accentuated by the similarities of the monsters to their opponents as much as the differences. ${ }^{54}$

\section{Conclusions}

Mrs Beaumont and Dracula are ultimately destroyed by the English professional middle classes, as represented in both works by doctors and lawyers, who achieve this victory with a combination of modern technology and a knowledge (medieval Christian or even preChristian) of traditional methods of dealing with the spiritual/social transgressor. This anticipates the posited 'solutions' for dealing with the 'problem' of migration and in particular Jewish migration at the turn of the twentieth century; technology (finger-prints, photographs, census forms, registration, border controls etc. for ascertaining numbers and locations of migrants, the machinery of the government, the police, and modern transport links to expel them). ${ }^{55}$ This was combined with a discourse drawing on an anti-Semitic tradition stretching back to the middle ages and stressing the expulsion of the Jews from England in 1290 as a precedent and an example. ${ }^{56}$

This is channelled into a ferocious physicality as the preferred means of dealing with the 'monster' and the migrant. The opponents of Count Dracula and Mrs Beaumont ultimately work outside the confines of an English legal system which protects the transgressor, whom they physically attack at the end of both stories with extreme violence. ${ }^{57}$ The most brutal parts of Dracula are those that describe the murder of the vampires, in particular the female vampires. The Great God Pan concludes with a graphic description of the death throes of 
Helen Vaughan, forced to commit suicide whilst her self-appointed judge watches, during which she undergoes the final of the many transformations that take place in the novella from woman to man, from human to animal and finally to 'worse than beast' (232). In the 1890s British anti-Semites used their literature to continually threaten Jewish refugees with a pogrom on the Eastern European model, if the mechanisms of the state were unable to deal with the migrant 'invasion'. ${ }^{58}$ In The Alien Invasion, W.H Wilkins warned that 'There are agitators in the East End of London who could arouse a Judenhetze tomorrow by merely holding up a finger. It is only the moderating influence of others which restrains them. ${ }^{59}$ British late-Victorian anti-migrant literature referred to the 'Russian method' of dealing with a Jewish demographic threat, i.e. extreme violence and enforced expulsion. In one chilling passage Arnold White mused on 'extermination' as a solution, ultimately dismissing this as '... impracticable on the verge of the twentieth century.' 60 This rhetorical violence permeated a society riven by doubts about its demographic present and future, an uncertainty that led to the scapegoating of various 'others' that threatened to transform this demography, particularly Jewish migrants, and that informed, whether acknowledged or not by the authors, the sensationalist prose and enduring gothic monsters of Arthur Machen and Bram Stoker.

\footnotetext{
${ }^{1}$ See Marlene Tromp, Maria K. Bachman and Heidi Kaufman (eds.) Fear, Loathing and Victorian Xenophobia (Columbus: Ohio State University Press, 2013)

${ }^{2}$ See David Glover, Literature, immigration and diaspora in fin-de-siècle England: A Cultural History of the 1905 Aliens Act (Cambridge: Cambridge University Press, 2012)

${ }^{3}$ Ludmilla Kostova, 'Straining the Limits of Interpretation: Bram Stoker's Dracula and its Eastern European Contexts' in John S. Bak (ed.), Post/Modern Dracula: From Victorian Themes to Postmodern Praxis

(Newcastle: Cambridge Scholars Pub., 2007) pp.13-30, at p.13.

${ }^{4}$ See The Journal of Dracula Studies.

${ }^{5}$ Stephen D. Arata 'The Occidental Tourist: "Dracula" and the Anxiety of Reverse Colonization', Victorian Studies, 33:4 (Summer, 1990), 621-45, p.623.

${ }^{6}$ Judith Halberstam, 'Technologies of Monstrosity: Bram Stoker's "Dracula"' in Victorian Studies, $36: 3$ (Spring 1993), 333-352, Carol Margaret Davison, Anti-Semitism and British Gothic Literature (Basingstoke: Palgrave Macmillan, 2004) chapter five and Howard L. Malchen, Gothic Images of Race in Nineteenth Century Britain (Stanford: Stanford University Press, 1996, pp.153-165. See David Glover, Vampires, Mummies and Liberals: Bram Stoker and the Politics of Popular Fiction (London: Duke University Press, 1996) and Glennis Byron,
} 
'Bram Stoker's Gothic and the Resources of Science' Critical Survey, 19:.2 (2007), pp.48-62 on Lombroso and Dracula. See Nick Groom, The Vampire: A New History (New Haven: Yale University Press, 2018) pp. 155-156 on the link between the vampire myth and the anti-Semitic 'blood libel'.

${ }^{7}$ Judith Halberstam, Skin Shows: Gothic Horror and the Technology of Monsters (London: Duke University Press, 1995), p.14.

8 Jules Zanger, 'A Sympathetic Vibration: Dracula and the Jews', English Literature in Transition, 31:1 (1991), pp.33-44, (at p.33).

${ }^{9}$ See Clive Leatherdale, Dracula: The Novel and the Legend (Brighton: Desert Island Books, 1993) which examines all of these points, and texts cited in note 6.

${ }^{10}$ See among others S.T Joshi, The Weird Tale (Austin: University of Texas Press, 1990) and James Machin, Weird Fiction in Britain, 1880-1939 (Basingstoke: Palgrave Macmillan, 2018)

${ }^{11}$ See David J. Skal, Hollywood Gothic: The Tangled Web of Dracula From Novel to Stage to Screen (London: Deutsche, 1992) and David J. Skal, The Monster Show: A Cultural History of Horror (London: Plexus, 1994).

${ }^{12}$ See Wesley D. Sweetser, Arthur Machen (New York: Twayne Publishers, Inc., 1964), pp. 157-8 for Machen's literary corpus. See S.T. Joshi, 'Introduction' in H.P Lovecraft, The Call of Cthulhu and Other Weird Stories (London: Penguin Books Ltd., 2002), p. xviii. Machen is referred to in a number of Lovecraft's short stories, including 'The Whisperer in the Darkness' (in which Lovecraft describes Machen's fiction as 'magnificent'), and The Great God Pan is explicitly named in 'The Dunwich Horror'. H.P. Lovecraft, 'The Whisperer in the Darkness' in The Call of Cthulhu and Other Weird Stories, pp. 200-67 at p.206; H.P Lovecraft, 'The Dunwich Horror' in The Thing on the Doorstep and Other Weird Stories (London: Penguin Books Ltd., 2001), pp. 206-45 at p.221. Lovecraft also devotes some space to Machen in his treatise, Supernatural Horror in Literature (H.P Lovecraft, Supernatural Horror in Literature (Toronto: Dover Publications Inc., 1973, pp88-95. For Lovecraft, Machen was 'master of an exquisitely lyrical and expressive prose style' (Lovecraft, Supernatural Horror, p.88)

${ }^{13}$ For Arthur Machen's personal interest in occult matters see Susan Johnston Graf, Talking to the Gods: Occultism in the Work of W.B Yeats, Arthur Machen, Algernon Blackwood and Dion Fortune (Albany: State University of New York Press, 2015) pp.57-78.

${ }^{14}$ See Adrian Eckersley, 'A Theme in the Early Work of Arthur Machen: "Degeneration"', English Literature in Transition, 1880-1920, 35:3 (1992) 276-287 and Aaron Worth, 'Arthur Machen and the Horrors of Deep History', Victorian Literature and Culture, 40:1 (2012) 215-227.

${ }^{15}$ Joshi, The Weird Tale p.21. Machin, Weird Fiction in Britain, chapter three. See also Christine Ferguson, 'Reading with the Occultists: Arthur Machen, A.E Waite and the Ecstasies of Popular Fiction, Journal of Victorian Culture, 21:1 (2016) 40-55, at p.50.

${ }^{16}$ See Mark Valentine, Arthur Machen (Bridgend: Seren, 1994), chapter two, Susan J. Navarette The Shape of Fear: Horror and the Fin-de-siècle Culture of Decadence (Lexington: University Press of Kentucky, 1998), chapter five, and Alexandra Warwick, 'Vampires and the Empire' in Sally Ledger and Scott McCracken (eds.) Cultural Politics at the Fin-de-siècle,(Cambridge: Cambridge University Press, 1995) pp.202-220, at p.207. One contemporary commentator, Harry Quilter, wrote of The Great God Pan that 'the author has spared no endeavour to suggest loathsomeness and horror which he describes as beyond the reach of words.' (Machin, Weird Fiction in Britain, p.141)

${ }^{17}$ W.H Wilkins, The Alien Invasion (London: Methuen and Co., 1892), p.18.

${ }^{18}$ Wilkins, The Alien Invasion, p.48.

${ }^{19}$ Joseph Banister, England Under the Jews (London: Self-Published, 1901), pp.36-37.

${ }^{20}$ Arnold White, The Modern Jew (London: William Heinemann, 1899), pp.xi-xii.

${ }^{21}$ Bram Stoker, Dracula (Reading: Penguin Popular Classics, 1994), p.30. All subsequent quotations are from this edition. Page numbers will follow in brackets in the text.

${ }^{22}$ Leatherdale, Dracula, p.109 and Elei Coundouriotis 'Dracula and the Idea of Europe' in Connotations, 9:2 (1999-2000) 143-159, p.155.

${ }^{23}$ Arthur Machen, 'The Great God Pan' in Roger Luckhurst (ed.), Late Victorian Gothic Tales (Oxford: Oxford University Press, 2015), p.197. All subsequent quotations are from this edition. Page numbers will follow in brackets in the text.

${ }^{24}$ See Philip Ball, 'They came from Outer Space... and Europe' in Prospect, June 2017, p.12.

${ }^{25}$ Arata 'The Occidental Tourist', p.630.

${ }^{26}$ Banister, England Under the Jews, p.10.

${ }^{27}$ For Machen's appreciation of and interest in his own Celto-Roman heritage see Sweetser, Arthur Machen, p.18.

${ }^{28}$ Beatrice Potter in Charles Booth, Life and Labour of the People in London, First Series: Poverty Vol. III, (London: Macmillan, 1902), p. 181.

${ }^{29}$ William Evans Gordon, The Alien Immigrant (London: William Heinemann, 1903), p. 12. 
${ }^{30}$ White, The Modern Jew, p.140.

${ }^{31}$ Julia Kristeva, Powers of Horror: An Essay on Abjection (New York: Columbia University Press 1982), p.185.

${ }^{32}$ White, The Modern Jew, p.xiv.

${ }^{33}$ White, The Modern Jew, p.55.

${ }^{34}$ Banister, England Under the Jews, p.99.

${ }^{35}$ See Christopher Frayling, The Yellow Peril: Dr Fu Manchu and the Rise of Chinophobia (London: Thames and Hudson, 2014)

${ }^{36}$ Anon. 'Foreign Undesirables' Blackwood's Magazine, No. MXXIV (February 1901), p.289.

${ }^{37}$ Navarette, The Shape of Fear, p.94.

${ }^{38}$ Leatherdale, Dracula: The Novel and the Legend, p.129.

${ }^{39}$ See William Hughes, 'A Singular Invasion: Revisiting the postcoloniality of Bram Stoker's Dracula' in Andrew Smith and William Hughes (eds.) Empire and the Gothic: The Politics of Genre (Basingstoke: Palgrave Macmillan, 2003), 88-102, at p.93, and Malchow, Gothic Images of Race, p.162.

${ }^{40}$ White, The Modern Jew, p.xvii.

${ }^{41}$ Malchow, Gothic Images of Race, p.150.

${ }^{42}$ Anthony Julius, Trials of the Diaspora: A History of Anti-Semitism in England (Oxford: Oxford University Press, 2010) p. 375.

${ }^{43}$ B. Fletcher Robinson, 'The Terror in the Snow' in Mark Valentine (ed.), The Werewolf Pack (Ware:

Wordsworth Editions Limited, 2008) 61-79, p.64.

${ }^{44}$ White, The Modern Jew, p.8.

${ }^{45}$ Hermann Taxis, A New Yet Ancient System of Politics or Problems of Great Britain at Home (London:

Simpkin, Marshall, Hamilton, Kent and Co., 1892), p.25.

${ }^{46}$ Banister, England Under the Jews, p.91.

${ }^{47}$ Banister, England Under the Jews, p.74.

${ }^{48}$ Banister, England Under the Jews, pp.97-98.

${ }^{49}$ Tony Taylor, The Politics of Reaction: The Ideology of the Cecils and the Challenge of Secular Education, 1889-1902 (Leeds: University of Leeds, 1997), p.28.

${ }^{50}$ See Matthew Gibson, Dracula and the Eastern Question (Basingstoke, Palgrave MacMillan, 2006), p.8, 'To see Dracula as a representation of the racial other... is too imprecise.' Carol Davison on the other hand in AntiSemitism and British Gothic Literature makes a case for viewing Dracula as a classic, even archetypal antiSemitic text.

${ }^{51}$ See William Hughes, Beyond Dracula: Bram Stoker's Fiction and its Cultural Context (Basingstoke: MacMillan, 2000), p.63 and pp.108-112. See also Warwick, 'Vampires and the Empire' pp.215-216.

${ }^{52}$ Christopher Frayling, Vampyres (London: Faber and Faber, 1991), pp.303-304.

${ }^{53}$ Hughes, 'A Singular Invasion' in Smith and Hughes (eds.) Empire and the Gothic, p.91.

${ }^{54}$ See Arata, 'The Occidental Tourist', p.639.

${ }^{55}$ See Montague Crackanthorpe, 'Should Government Interfere?' in Arnold White, The Destitute Alien in Great Britain, (London, 1892) p.61-65. See David Punter, 'Bram Stoker's Dracula: Traditions, Technology, Modernity' 31-44, in Bak (ed.) Post/Modern Dracula.

${ }^{56}$ White, The Modern Jew, p.xii-xiii.

${ }^{57}$ Carol A. Senf, "Dracula": The Unseen Face in the Mirror' in The Journal of Narrative Technique, 9:3 (Fall, 1979), 160-170, at p.163.

${ }^{58}$ Malchow, Gothic Images of Race, p.161.

${ }^{59}$ Wilkins, The Alien Invasion, p.52.

${ }^{60}$ White, The Modern Jew, p.11. 